ISSN 2614-2775 (Print)

Tahun 2022

ISSN 2621-8143 (Online)

\title{
HELLISON MODEL HYBRIDATION WITH PROJECT BASED LEARNING (PjBL) ON RESPONSIBILITY IN ONLINE LEARNING
}

\author{
Defri Mulyana $^{1}$, Deni Setiawan ${ }^{2}$, Randy Fadillah Gustaman ${ }^{3}$ \\ Universitas Siliwangi ${ }^{1,2,3}$ \\ defrimulyana@unsil.ac.id, denisetiawan@unsil.ac.id, randy.fadillah@unsil.ac.id
}

\begin{abstract}
The importance of fostering responsible attitudes during online learning so that students' responsible attitudes can be formed through the habit of carrying out responsible behavior. Through practice-based course learning, it is hoped that students' attitudes of responsibility will be better. Because in practice-based courses not only aspects of skills are developed, but the formation of other aspects is developed in it through movement activities. The need for a learning model with an online concept that matches the characteristics of the student's attitude of responsibility so that the problems encountered can be handled appropriately. The researcher tried to unite the Hellison learning model and the Project Based Learning (PBL) model, considering that the researcher chose the helison model, which is one of the social reconstruction models that is suitable for problems regarding the attitude of responsibility, from the results of data analysis in this study, the probability value (sig. ) for responsibility is $0.000<0.05$. Thus, HO is rejected, meaning that the Hybridization of the Hellison and PjBL models between the before and after tests has a significant effect on responsibility in the experimental group. Thus the Hellison model and the PjBL learning model are applied to foster students to understand the attitude of responsibility when participating in learning and practice a sense of personal responsibility (self-responsibility) which is packaged in a practicebased online learning.
\end{abstract}

Keywords: Hellison Model Hybridization, Project Based Learning Model, Responsibility

Accepted: $25^{\text {th }}$ of January 2022

Correspondence author: Defri Mulyana, Universitas Siliwangi, Indonesia. E-Mail: defrimulyana@unsil.ac.id

DOI http://dx.doi.org/10.31851/hon.v5i1.6840 do

(c) (i) (2)

Jurnal Halaman Olahraga Nusantara licensed under a Creative Commons Attribution-ShareAlike 4.0 International License

\section{INTRODUCTION}

Online learning is a type of learning that relies on an internet connection in the implementation of the learning process. Furthermore, online learning is also defined as learning that integrates an internet connection using the teaching and learning process. Online learning or virtual learning is believed to be a new frame of mind in the learning process because it can be done using a very easy way without having to meet face to 315 | Halaman Olahraga Nusantara copyright@Defri Mulyana 
face in a classroom using only an internet connection-based implementation so the learning process can take place.

This type of learning is also observed to increase student engagement in the learning process. According to the Ministry of Education and Culture (2020) online learning or commonly known as E-learning, has six main principles: 1. Learning is open (learning is open) 2. Learning is social (learning is social) 3. Learning is personal (learning is personal) 4. Learning is augmented (learning is assisted) 5. Learning is multi-represented (learning is multi-represented / multiperspective) 6. Learning is mobile (learning is moving). Of course, online learning tools or media are needed that can fulfill these six aspects. Some online learning media that can be used as a liaison between teachers and students are Learning Management Systems (such as Moodle, Edmondo, and Google Classroom services), live streaming media (such as Zoom, CloudX or Google Meet), group chat applications (such as WhatsApp or Telegram), and other online media (such as YouTube, Kahoot and Quizizz).

At this time, online platforms that are often used by many universities in conducting teaching and learning processes are Zoom and Google Classroom. Zoom is a video conferencing service that has the easy ability to present an online meeting atmosphere, according to (Achmad Jayul, Edi Irwanto , 2020) said: Learning is basically a process of interaction between educators and students, both direct (face-toface) and indirect interactions. direct (learning activities using learning media in web applications). In the midst of the COVID-19 pandemic, teaching and learning activities are recommended to use an online learning model. Not all online learning methods can be used in the physical education learning process related to the practical psychomotor (motion) aspects. The method that has a video application can be used in the physical education learning process. Learning in the new normal era can be carried out online (in network), offline (outside the network) or a combination of the two which is better known as blanded learning (Rahman et al., 2021) 
Meanwhile, Google Classroom is an efficient portal service to make it easier for teachers to manage teaching materials and assignments. Whatsapp group/group chat is a complementary medium of what the researcher has conveyed to Google Classroom. Online learning is considered an innovative approach that is designed in such a way, student-centered, interactive, and able to facilitate a conducive learning environment for anyone, anywhere, and anytime by using digital technology integrated with various forms of accessible and natural learning materials. flexible. This indicates that lecturers must have sufficient capabilities in the use of technology, especially digital and also sufficient readiness to be able to facilitate the learning needs of students with learning environment conditions that may vary. In addition, the implementation of online learning must also be able to make students the center of all learning activities and be able to increase student active participation not only with lecturers, but also with fellow students and also with learning materials. Basically, every learning media has advantages and disadvantages. For this reason, it is necessary to carry out continuous evaluation so that online learning patterns can take place effectively.

The development of competency aspects in learning does not only develop one aspect to get maximum learning outcomes from learning. According to (Suherman, 2009), "learning outcomes are expected to change in all aspects such as changes in attitudes, knowledge, and skills. Learning outcomes are in the form of attitudes and behaviors shown by students in the form of honesty, mental strength, discipline and responsibility. Good learning outcomes are influenced by a good learning process as well. According to the Minister of Education and Culture Number 3 of 2020 states that "The characteristics of the learning process as referred to in Article 11 paragraph (1) letter a consist of interactive, holistic, integrative, scientific, contextual, thematic, effective, collaborative, and student-centered properties.". Therefore, learning is made so that students can carry out the process well so that it has a positive impact on their growth and development. 
Education is given to help the growth and development of students to be balanced between spiritual aspects, social aspects, knowledge and skills so that children's growth and development are for the better. However, in practice, there are many obstacles that educators must face in presenting a good learning with online concepts, especially in practice-based courses regarding the attitude of student responsibility in participating in the teaching and learning process to achieve a good teaching and learning process.

The obstacle that must be faced in the implementation of online learning is the lack of student responsibility in participating in physical education learning. Many factors influence, there are students who actively participate in learning, there are also students who reduce the quality of learning due to the attitude of responsibility has not been formed properly due to the lack of direct conditioning or control from the lecturer. Students whose attitude of responsibility is not good before, during and after participating in physical education learning causes disruption of the teaching and learning process. Students who have a responsibility attitude problem if they are not given guidance will cause the learning carried out by the lecturer to be not optimal and the learning indicators that have been determined are not achieved properly, therefore it is necessary to develop an attitude that is integrated with the learning carried out by the lecturer. Teaching of responsibility and develop of good character in schools is sometimes not implemented com-prehensively and well programmed because low of per-ception, acceptance and optimism of all educational tools (teachers, students, schools, parents). The main problem lies in the fact that teachers, parents, and stu-dents alike are not accepting Character Education with open arms (Chapman, 2011).

The importance of fostering responsible attitudes during online learning so that students' responsible attitudes can be formed through the habit of carrying out responsible behavior. The fostering of an attitude of responsibility applied by lecturers to students should be carried out consistently and firmly so that the effects of fostering 318 | Halaman Olahraga Nusantara copyright@Defri Mulyana 
an attitude of responsibility can be formed. Through practice-based course learning, it is hoped that students' attitudes of responsibility will be better. Because in practicebased courses not only aspects of skills are developed, but the formation of other aspects is developed in it through movement activities. The need for a learning model with an online concept that matches the characteristics of the student's attitude of responsibility so that the problems encountered can be handled appropriately.

This research tries to do Hellison hybridization with $\mathrm{PjBL}$ by programmed, organized, and fulfilling the research Models-based Practice also hybridizing cooperative Learning and Teaching for Personal and Social Respon-sibility (Rio, 2014); Hybridizing Sport Education and Teaching for Personal and Social Responsibility to in-clude students with disabilities (Menendez \& Rio, 2017).

The researcher tried to unify the Hellison learning model and the Project Based Learning (PBL) model, the consideration of the researcher choosing the helison model, which is one of the social reconstruction models that is suitable for problems regarding the attitude of responsibility, the Hellison learning model is applied to foster students to understand the attitude of responsibility while participating in learning and practicing a sense of personal responsibility (self-responsibility) which is packaged in a practice-based online learning. According to (Suherman, 2009), "Hellison's model was created to help students understand and practice a sense of personal responsibility (self-responsibility)." This Hellison learning model trains students to understand their own responsibilities and practice a sense of responsibility.

Personal responsibility which is divided into 5 levels of attitude, namely level 0 (irresponsibility), level 1 (self-control), level 2 (involvement), level 3 (responsible), and level 4 (caring), while the project based learning model $(\mathrm{PjBL})$ learning model that is centered on students and provides a meaningful learning experience for students. Students' learning experiences and concepts are built based on the products produced in the project-based learning process. to a topic. Students constructively carry out 


\section{OLAHRAGA}

IURIAL JLIII KROL DURAQLAH
Jendral A. Yani Street Lorong Gotong Royong 9/10 Ulu Palembang South Sumatera

email jurnal: jurnalhon@univpgri-palembang.ac.id situs web: http://www.univpgri-palembang.ac.id

\section{Accredited}

SINTA 3

deepening learning with a research-based approach to problems and questions that are weighty, real, and relevant. In the PjBL model, students not only understand the content, but also develop skills in students how to play a role in society.

Skills developed in $\mathrm{PjBl}$ include communication and presentation skills, organizational and time management skills, research and investigation skills, selfassessment and reflection skills, group participation and leadership, and critical thinking. Performance assessment on PjBL can be done individually by taking into account the quality of the product produced, the depth of understanding of the content shown, and the contribution made to the ongoing project realization process. $\mathrm{PjBL}$ also allows students to reflect on their own ideas and opinions, and make decisions that affect project outcomes and the learning process in general, and present the final product.

Therefore, researchers are interested in hybridizing two learning models, namely the Hellison model and Project Based Learning (PjBL) as a solution to the learning formula carried out with online concepts. This study is intended to determine the effectiveness of Hellison's learning model and Project Based Learning (PjBL) in shaping student responsibility during online learning. The researchers put this in a quasi-experimental study entitled "Hybridization of the Hellison Model with Project Based Learning (PjBL) on Responsibility in Online Learning".

\section{METHOD}

An experimental research needs an appropriate research design, according to the needs of the variables contained in the research design. The research design in this study is "Pre-test and Post-test design" which is described as follows (Fraenkel and Wallen, 1993):

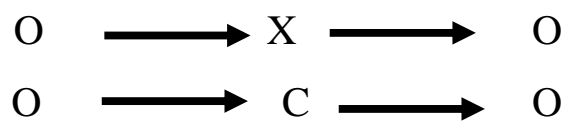

Figure 1. Desain Eksperimen Pre-test and Post-test design 


\section{Research variable}

The variable is the object of research, or what is the point of attention of a study (Suharsimi Arikunto, 2010:161). Meanwhile, according to Sutrisno Hadi (2000:224) what is meant by variables are symptoms that show variations, both in type and in level. The independent variable in this study is the Hybridization of Helison Learning Model and Project Based Learning (PjBL) and the dependent variable is the responsibility in online learning.

\section{Population, Sampling And Sampling Techniques}

The population is the entire population that is intended to be investigated, and the population is limited by a number of residents or individuals who have at least the same characteristics (Sutrisno Hadi, 2000). The population is also defined as the entire research subject (Suharsimi Arikunto, 2010). The population in this study were all students who contracted the futsal course, Department of Physical Education, FKIP Siliwangi University, amounting to 85 people.

The sample is part or representative of the population under study (Arikunto, 2010). According to (Sutrisno Hadi, 2000), what is meant by the sample is a number of residents whose numbers are less than the total population. Sampling must be representative, in the sense that all characteristics of the population should also be reflected in the sample taken.

According to (Arikunto, 2006) if the subject is less than 100, it is better to take all of them so that the research is a population study. Furthermore, if the number of subjects is large, $10-15 \%$ or more can be taken depending at least on the ability of the researcher in terms of time, effort, and cost. In accordance with this opinion, the sample used in this study was 85 students who contracted a futsal course at the Department of Physical Education, FKIP Siliwangi University, totaling 85 people. The technique used in this research is total sampling. 


\section{Research Instruments}

Research instruments are tools or facilities used by researchers in collecting data so that their work is easier and the results are better, in the sense that they are more accurate, complete, and systematic so that they are easier to process. Variations in the types of research instruments are: questionnaire, checklist or checklist, interview guide, observation guide. Ceklis itself has various forms (Suharsimi Arikunto, 2010:203). The research instrument used in this research is the Responsibility Questionnaire In responsibility because what will be measured is attitude, a Likert scale is used, with the following options: Strongly agree, if on very few occasions the respondent experiences the things listed in the item

a) Agree, if on very few occasions the respondent experiences the things listed in the item

b) Doubtful, if on several occasions the respondent experiences the things listed in the item

c) Disagree, if on most occasions the respondent experiences the things listed in the item

d) Strongly Disagree, if on almost every occasion the respondent experiences the things listed in the item In each of these measuring instruments, each item has a value of 1 to 5 with a certain weight. The weights are as follows:

Table 1. Weighting of each option

\begin{tabular}{llc}
\hline No. & \multicolumn{1}{c}{ Option } & Score \\
\hline 1. & SS (Strongly Agree) & 5 \\
2. & S (Agree) & 4 \\
3. & R(Ragu-ragu) & 3 \\
4. & TS(Disagree) & 2 \\
5. & STS (Strongly Disagree) & 1 \\
\hline
\end{tabular}

Based on the subject's answer by considering the type of question, there are two types of questions, namely positive items (favorable) and negative items (Unfavorable). For positive items with the answer 'Always' getting a value of 5 and the 
answer 'Never' getting a value of 1 . On the contrary for negative items, the answer 'Never' gets a value of 1 and the answer 'Always' gets a value of 5 .

The assessment for the responsibility questionnaire uses a Likert measurement method approach known as the Summated Rating Scale, namely every written statement can be agreed as a favorable statement or an unfavorable statement, where the subject responds to each item by using the level (intensity) of agreement or disagreement with the statements. the. The scores are then added up. In this scale, what is to be achieved is to place individuals at certain points on the continuum of agreement and disagreement with statements.

Summated Rating Scales have the following characteristics:

a) A priori in nature because of its arrangement, the answer value has been determined based on the selected alternative answers, where each answer has a certain weight

b) The value of the scale in the psychological continuum is not known objectively, the numbers in the continuum are not known, therefore it is ordinal

c) Each statement (item) can be positive or negative and each has 5 alternative answers

d) Each respondent's answer shows the level of the position of the attitude concerned with the object being measured

In line with the opinion of Dawes, (John, 2008) who said A method of likert be considered as the first ones to approach it with measuring broad / it the opinion of respondents not only to the answer yes or not. The Likert method can be said to be the first to take an approach by measuring the breadth/depth of the opinion of the respondents, not just by answering "yes" or "no".

\section{DISCUSSON}

The hybridization of two learning models (Hellison and Project Based Learning) has a significant effect on responsibility. Paired sample t-test was used to 


\section{OLAHRAGA}

MRIAL HAII KEOLIMRIGLA
Jendral A. Yani Street Lorong Gotong Royong 9/10 Ulu Palembang South Sumatera

email jurnal: jurnalhon@univpgri-palembang.ac.id situs web: http://www.univpgri-palembang.ac.id

\section{Accredited}

SINTA 3

process data from the test results before and after tests. Processing is carried out to determine the effect of the experiments carried out, by testing the difference between the average test results before and after tests. The test is carried out on two sides, where the probability value (sig.) and dk are each divided by 2 .

Table 2. Paired Samples Test

\begin{tabular}{|c|c|c|c|c|c|}
\hline & & \multicolumn{4}{|c|}{ Paired Differences } \\
\hline & & Mean & $\begin{array}{c}\text { Std. } \\
\text { Deviation }\end{array}$ & $\begin{array}{l}\text { Std. } \\
\text { Error } \\
\text { Mean }\end{array}$ & $\begin{array}{l}95 \% \text { Confidence } \\
\text { Interval of the } \\
\text { Difference } \\
\text { Lower }\end{array}$ \\
\hline $\begin{array}{l}\text { Pair } \\
1\end{array}$ & $\begin{array}{l}\text { Pre-Tes Eksperimen } \\
\text { - Post-Test } \\
\text { Eksperimen }\end{array}$ & 1.329 & .918 & .100 & -1.527 \\
\hline
\end{tabular}

Table 3. Paired Samples Test

Paired Differences

95\% Confidence Interval of

the Difference

Sig. (2-

\begin{tabular}{llrrrr} 
& & Upper & $\mathrm{t}$ & df & \multicolumn{1}{c}{ tailed) } \\
\hline Pair & Pre-Tes Eksperimen - Post- & -1.131 & -84 & .000 \\
1 & Test Eksperimen & & 13.353 & \\
\hline
\end{tabular}

It is known that the probability value (sig.) for responsibility is $0.000<0.05$. Thus, HO is rejected, meaning that Hybridization of the Hellison and PjBL models between the before and after tests has a significant effect on responsibility in the experimental group.

This experimental research is a research conducted by researchers for the need to increase character formation in online learning through learning futsal courses, especially studying tactical material in futsal learning. In order to increase the formation of this character, the researcher uses the sport of futsal in the process of online teaching and learning activities. This is one of the important aspects for improving the quality of character 


\section{CONCLUSION}

Based on the results of data processing and analysis that the author has done, the conclusions are as follows: There is a significant effect of Hybridization of the Hellison Model and the Project Based Learning (PjBL) Learning Model on student responsibility in online learning.

The results of this study need to be followed up by trying various learning models apart from the models that the researchers researched in order to provide benefits and positive impacts for the whole community, especially in the world of educators. The next follow-up is a plan for the stages that researchers will do in the future, including the following:

The results of this study are expected to be useful from a practical point of view for various parties, including:

\section{Lecturer}

To improve the quality of teaching and apply the learning model as a learning innovation at this time.

2. Student

With innovation in learning, students will get various variations in learning. So, students are not bored with learning which is very monotonous at first and students are always eager to learn.

3. College

The results of this study can be used as material for consideration for the Department of Physical Education to develop a learning model. And improve the quality of life of students through quality learning activities.

\section{REFERENCES}

Achmad Jayus, Edi Irwanto (2020). Model Pembelajaran Daring Sebagai Alternatif Proses Kegiatan Belajar Pendidikan Jasmani di Tengah Pandemi Covid-19. Jurnal Pendidikan Kesehatan Rekreasi P-ISSN 2337-9561 Vol. 6, No. 2, Hal. 190 - 199, Juni 2020 E-ISSN 2580-1430DOI : 10.5281/zenodo. 
Jendral A. Yani Street Lorong Gotong Royong 9/10 Ulu Palembang South Sumatera

email jurnal: jurnalhon@univpgri-palembang.ac.id situs web: http://www.univpgri-palembang.ac.id

\section{Accredited}

SINTA 3

Agus Zaenul Fitri, 2012, Pendidikan Karakter Berbasis Nilai dan Etika di Sekolah, Jogjakarta : Ar-Ruzz Media

Ardi Novan Wiyani. 2013. Manajemen Kelas. Yogjakarta : Ar-Ruzz Media

Arikunto, S.(2010). Prosedur Penelitian : Suatu Pendekatan Praktik.Jakarta: Rineka Cipta.

Chapman, Alicia M. (2011). implementing character education into school curriculum. ESSAI, Vol. 9, Article 11.

Frankel, Jack R dan Norman E. Wallen. (1993). How to design and Evaluate Research in Education. 2ndedition. New York: McGraw hill Inc.Sutresna 2002

Grant, M.M. (2002). Getting a Grip on Project-Based Learning : Theory, Cases and Recommendations. A Middle School Computer Technologies Journal

Hadi, Sutrisno,2000,Metodologi Research. Yogyakarta : Andi Yogyakarta

Kemendikbud. 2020. Surat Edaran No. 4 Tahun 2020 Tentang Pelaksanaan Kebijakan Pendidikan Dalam Masa Darurat Penyebaran CORONAVIRUS DISESASE (Covid-19).

Menendez, J.I \& Rio, J.F (2017), Hybridising Sport Education and Teaching for Personal and Social Re-sponsibility to include students with disabilities, European Journal of Special Needs Education.

Permendikbud (2020). Peraturan menteri pendidikan dan Kebudayaan Nomor 3 tahun 2020 Tentang Standar Nasional Pendidikan

Rio, J.F (2014), Another Step in Models-based Practice: Hybridizing Cooperative Learning and Teaching for Personal and Social Responsibility, Journal of Physi-cal Education, Recreation \& Dance, 85:7, 3-5,

Suherman, Adang. (2009). Revitalisasi Pengajaran Dalam Pendidikan Jasmani. Bandung: CV. Bintang WarliArtika.

Taufik Rahman, Dyas Andry Prasetyo, Hendra Mashuri, (2021) The Impact Of Online Learning During The Covid-19 Pandemic On Physical Education Teachers. Jurnal Halaman Olahraga Nusantara ISSN 2621-8143 Vol. 4, No. 2, Hal. 294 - 304, Februari 2021 Doi 10.31851/hon.v4i2.5638.

Yaumi, M. 2014. Pendidikan Karakter: Landasan, Pilar, dan Implementasi. Jakarta: Predana Media Group 